\title{
Analysis of predicted and observed accumulated convective precipitation in the area with frequent split storms
}

\author{
M. Ćurić and D. Janc \\ Institute of Meteorology, University of Belgrade, 11000 Belgrade, Serbia \\ Received: 26 May 2011 - Published in Hydrol. Earth Syst. Sci. Discuss.: 22 July 2011 \\ Revised: 9 November 2011 - Accepted: 24 November 2011 - Published: 6 December 2011
}

\begin{abstract}
Convective clouds generate extreme rainfall events and flash floods in small areas with both large spatial and temporal variability. For this reason, the monitoring of the total accumulated precipitation fields at the surface with rain gauges and meteorological radars has both strengths and weakness. Alternatively, a numerical cloud model may be a useful tool to simulate convective precipitation for various analyses and predictions. The main objective of this paper is to show that the cloud-resolving model reproduces well the accumulated convective precipitation obtained from the rain gauge network data in the area with frequent split storms. We perform comparisons between observations and model samples of the areal accumulated convective precipitation for a 15-year period over treated area. Twenty-seven convective events have been selected. Statistical analyses reveal that the model areal accumulated convective precipitation closely match their observed values with a correlation coefficient of 0.80 .
\end{abstract}

\section{Introduction}

Flash floods in small areas leading to huge material damage and loss of life are mainly caused by convective precipitation. The correct reproduction of both its spatial and temporal distribution contributes to the improvements on hydrological analysis and predictions. Meteorologists have two main tools to estimate convective precipitation at the ground: rain gauge and meteorological radar data. Although rain gauges measure accumulated precipitation accurately, the spatial pattern of convective precipitation is poorly represented due to the limited resolution and spot-like coverage of the observational network (Barnolas et al., 2010). Meteorological radars may

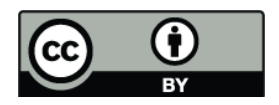

Correspondence to: M. Ćurić (curic@ff.bg.ac.rs) be a better option in little basins or in regions where convection is important. However, radar data have important disadvantages because they are an indirect measure of rainfall (Uijlenhoet and Pomeroy, 2001) and with worse results of rainfall depth in a given location compared to rain gauge data (Hunter, 1996; Young et al., 1999). Many studies, therefore, have been realized to minimize radar errors (Chumchean et al., 2006).

Various rainfall models are developed depending on the availability of radar data and the rain gauge network spatial resolution (Willems, 2001; Sayed et al., 2003). Despite that, the best approach is to use various numerical cloud models that are capable of simulating the accumulated convective precipitation with a higher spatial and temporal resolution independently of availability of radar data and rain gauge network density. This is important to predict and reconstruct the accumulated convective precipitation fields as inputs to the hydrological models (Droegemeier et al., 2000; Richard et al., 2003; Gilmore et al., 2004b; Bongioannini Cerlini et al., 2005). The improvement of model microphysics is essential because convective precipitation is very sensitive to the uncertainties in cloud microphysics (Gilmore et al., 2004a,b; Spiridonov and Ćurić, 2005). The choice of a hydrometeor size distribution is critical for the cloud model outputs (Ćurić et al., 1998; Cohen and McCaul, 2006). There are studies that use the meteorological models to simulate the convective precipitation over a large area as well as to compare the modeled and observed datasets (e.g. Amengual et al., 2007). Recently, comparison of the long-term samples of observed and model areal accumulated convective precipitation from isolated storms show the capability of the cloud-resolving model to match observations in mountainous and flat land areas (Ćurić and Janc, 2011a).

The complex feature of the accumulated convective precipitation in a small area is affected by the storm cell structure. Some convective storms contain essentially only one kind of cell. Others contain a mixture of ordinary cells and

Published by Copernicus Publications on behalf of the European Geosciences Union. 


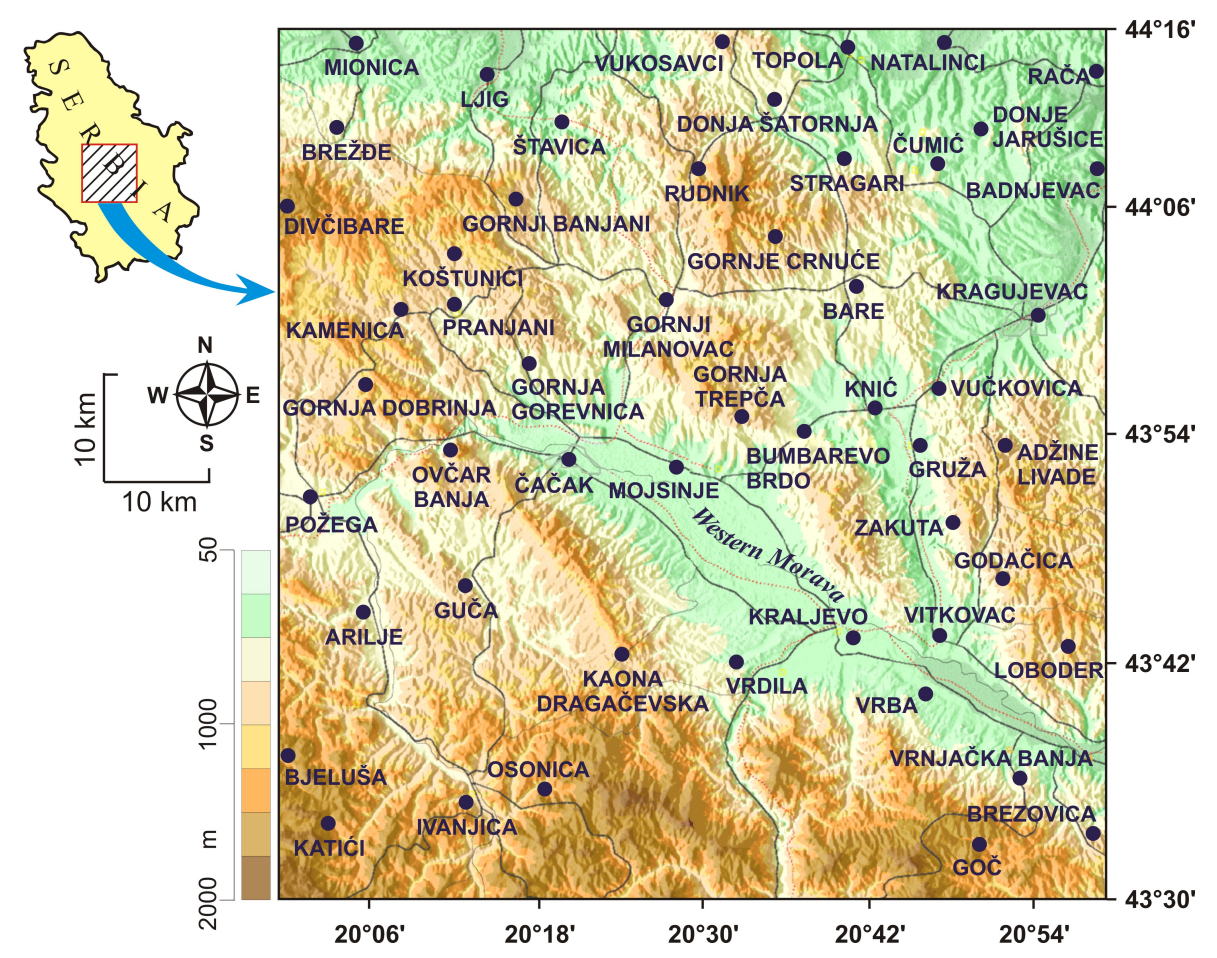

Fig. 1. Study area with rain gauge network.

supercells either simultaneously or at different times. However, convective storm splitting and subsequent split motion affect the most complex spatial convective precipitation pattern. Split right- and left-moving storms are cyclonic and anticyclonic, respectively (Adlerman et al., 1999; Ćurić and Janc, 2011b). Each split storm also contains one or more cells and may split again (Ćurić et al., 2009). Split storms are not mirror images of each other. Observational evidence shows that the right-moving storms are favored in the environment characterized by clockwise-turning hodographs. There are, however, the long-lived left-moving convective storms within environments with the same wind shear conditions (Grasso and Hilgendorf, 2001). The importance of the storm splitting process is also recognized in urban areas (Niyogy et al., 2011). The knowledge of the spatial pattern of convective precipitation herein is necessary due to the drainage requirements. We must also emphasize that radar data give a weak estimation of convective precipitation intensity associated with the splitting processes. For this reason, hydrometeorologists must find another effective tool to estimate the convective precipitation in such a complex scenario.

Bearing the above considerations in mind, the main objective of this paper is to show whether the cloud-resolving model can simulate well convective precipitation in an area with frequent storm splitting episodes. We use a cloudresolving mesoscale model with substantially improved microphysics and initial conditions (Ćurić and Janc, 2011a) to reproduce well the observed accumulated convective precipitation in this area. We compared the modeled and observed amounts of areal accumulated convective precipitation by using a statistical analysis. Correct description of the convective precipitation in space and time in this complex case would be essential with regard to various meteorological and hydrological predictions and analyses.

\section{Study area and data}

For the purpose of this study we select the area in the west part of Serbia in which split storms occur frequently and may cause flash floods. This area is situated at a northern latitude between $43^{\circ} 30^{\prime} \mathrm{N}$ and $44^{\circ} 16^{\prime} \mathrm{N}$ and eastern longitude between $20^{\circ}$ and $21^{\circ} \mathrm{E}$ (Fig. 1). The most prominent region of this mountainous area is the centrally located West Morava river valley which is roughly oriented from northwest to southeast. The valley floor is flat and very narrow, especially in the middle. The southern valley side has higher mountains with peak values over $1.5 \mathrm{~km}$ above the valley floor. This valley is affected by convective events with flash floods that are often produced by the NW air mass convective storms. These storms were initialized frequently over the Zlatibor plateau (west from the treated area) with a mean height of approximatively $1 \mathrm{~km}$ m.s.l. in agreement with Ćurić (1982) and Ćurić and Janc (1992).

The convective precipitation data were collected from the rain gauge network presented in Fig. 1. The geographical 
Table 1. Geographic coordinates and altitudes of rain gauge stations in the study area.

\begin{tabular}{|c|c|c|c|c|c|c|c|}
\hline $\begin{array}{l}\text { rain gauge } \\
\text { stations }\end{array}$ & latitude & longitude & $\begin{array}{l}\text { altitude } \\
\text { (m) }\end{array}$ & $\begin{array}{l}\text { rain gauge } \\
\text { stations }\end{array}$ & latitude & longitude & $\begin{array}{r}\text { altitude } \\
(\mathrm{m})\end{array}$ \\
\hline Mionica & $44^{\circ} 15^{\prime} \mathrm{N}$ & $20^{\circ} 05^{\prime} \mathrm{E}$ & 170 & Gruža & $43^{\circ} 53^{\prime} \mathrm{N}$ & $20^{\circ} 47^{\prime} \mathrm{E}$ & 260 \\
\hline Koštunići & $44^{\circ} 05^{\prime} \mathrm{N}$ & $20^{\circ} 12^{\prime} \mathrm{E}$ & 580 & Adžine Livade & $43^{\circ} 54^{\prime} \mathrm{N}$ & $20^{\circ} 53^{\prime} \mathrm{E}$ & 580 \\
\hline Pranjani & $44^{\circ} 01^{\prime} \mathrm{N}$ & $20^{\circ} 13^{\prime} \mathrm{E}$ & 420 & Knić & $43^{\circ} 56^{\prime} \mathrm{N}$ & $20^{\circ} 43^{\prime} \mathrm{E}$ & 320 \\
\hline Vukosavci & $44^{\circ} 15^{\prime} \mathrm{N}$ & $20^{\circ} 31^{\prime} \mathrm{E}$ & 360 & Ovčar Banja & $43^{\circ} 54^{\prime} \mathrm{N}$ & $20^{\circ} 12^{\prime} \mathrm{E}$ & 280 \\
\hline Natalinci & $44^{\circ} 15^{\prime} \mathrm{N}$ & $20^{\circ} 48^{\prime} \mathrm{E}$ & 130 & Čačak & $43^{\circ} 53^{\prime} \mathrm{N}$ & $20^{\circ} 19^{\prime} \mathrm{E}$ & 250 \\
\hline Rača & $44^{\circ} 14^{\prime} \mathrm{N}$ & $20^{\circ} 59^{\prime} \mathrm{E}$ & 270 & Požega & $43^{\circ} 50^{\prime} \mathrm{N}$ & $20^{\circ} 02^{\prime} \mathrm{E}$ & 310 \\
\hline Ljig & $44^{\circ} 13^{\prime} \mathrm{N}$ & $20^{\circ} 15^{\prime} \mathrm{E}$ & 150 & Mojsinje & $43^{\circ} 53^{\prime} \mathrm{N}$ & $20^{\circ} 29^{\prime} \mathrm{E}$ & 230 \\
\hline Stavice & $44^{\circ} 11^{\prime} \mathrm{N}$ & $20^{\circ} 20^{\prime} \mathrm{E}$ & 225 & Zakuta & $43^{\circ} 50^{\prime} \mathrm{N}$ & $20^{\circ} 49^{\prime} \mathrm{E}$ & 300 \\
\hline Donja Šatornja & $44^{\circ} 12^{\prime} \mathrm{N}$ & $20^{\circ} 37^{\prime} \mathrm{E}$ & 320 & Bumbarevo Brdo & $43^{\circ} 54^{\prime} \mathrm{N}$ & $20^{\circ} 38^{\prime} \mathrm{E}$ & 350 \\
\hline Breždje & $44^{\circ} 11^{\prime} \mathrm{N}$ & $20^{\circ} 03^{\prime} \mathrm{E}$ & 340 & Godačica & $43^{\circ} 46^{\prime} \mathrm{N}$ & $20^{\circ} 52^{\prime} \mathrm{E}$ & 295 \\
\hline Donje Jarušice & $44^{\circ} 11^{\prime} \mathrm{N}$ & $20^{\circ} 52^{\prime} \mathrm{E}$ & 240 & Arilje & $43^{\circ} 45^{\prime} \mathrm{N}$ & $20^{\circ} 06^{\prime} \mathrm{E}$ & 350 \\
\hline Rudnik & $44^{\circ} 09^{\prime} \mathrm{N}$ & $20^{\circ} 30^{\prime} \mathrm{E}$ & 635 & Guča & $43^{\circ} 46^{\prime} \mathrm{N}$ & $20^{\circ} 14^{\prime} \mathrm{E}$ & 360 \\
\hline Stragari & $44^{\circ} 09^{\prime} \mathrm{N}$ & $20^{\circ} 40^{\prime} \mathrm{E}$ & 260 & Kaona-Dragačevska & $43^{\circ} 43^{\prime} \mathrm{N}$ & $20^{\circ} 25^{\prime} \mathrm{E}$ & 570 \\
\hline Ćumić & $44^{\circ} 08^{\prime} \mathrm{N}$ & $20^{\circ} 49^{\prime} \mathrm{E}$ & 365 & Vrdila & $43^{\circ} 43^{\prime} \mathrm{N}$ & $20^{\circ} 35^{\prime} \mathrm{E}$ & 245 \\
\hline Badnjevac & $44^{\circ} 08^{\prime} \mathrm{N}$ & $20^{\circ} 59^{\prime} \mathrm{E}$ & 165 & Kraljevo & $43^{\circ} 44^{\prime} \mathrm{N}$ & $20^{\circ} 41^{\prime} \mathrm{E}$ & 219 \\
\hline Gornji Banjani & $44^{\circ} 06^{\prime} \mathrm{N}$ & $20^{\circ} 16^{\prime} \mathrm{E}$ & 470 & Vrba & $43^{\circ} 41^{\prime} \mathrm{N}$ & $20^{\circ} 47^{\prime} \mathrm{E}$ & 190 \\
\hline Gornje Crnuće & $44^{\circ} 05^{\prime} \mathrm{N}$ & $20^{\circ} 35^{\prime} \mathrm{E}$ & 600 & Bjeluša & $43^{\circ} 36^{\prime} \mathrm{N}$ & $20^{\circ} 01^{\prime} \mathrm{E}$ & 860 \\
\hline Pranjani & $44^{\circ} 01^{\prime} \mathrm{N}$ & $20^{\circ} 13^{\prime} \mathrm{E}$ & 420 & Katići & $43^{\circ} 34^{\prime} \mathrm{N}$ & $20^{\circ} 04^{\prime} \mathrm{E}$ & 1010 \\
\hline Divčibare & $44^{\circ} 07^{\prime} \mathrm{N}$ & $20^{\circ} 00^{\prime} \mathrm{E}$ & 960 & Ivanjica & $43^{\circ} 35^{\prime} \mathrm{N}$ & $20^{\circ} 14^{\prime} \mathrm{E}$ & 465 \\
\hline Gornji Milanovac & $44^{\circ} 03^{\prime} \mathrm{N}$ & $20^{\circ} 29^{\prime} \mathrm{E}$ & 365 & Osonica & $43^{\circ} 36^{\prime} \mathrm{N}$ & $20^{\circ} 19^{\prime} \mathrm{E}$ & 680 \\
\hline Topola & $44^{\circ} 15^{\prime} \mathrm{N}$ & $20^{\circ} 42^{\prime} \mathrm{E}$ & 250 & Kamenica & $44^{\circ} 01^{\prime} \mathrm{N}$ & $20^{\circ} 09^{\prime} \mathrm{E}$ & 460 \\
\hline Bare & $44^{\circ} 03^{\prime} \mathrm{N}$ & $20^{\circ} 42^{\prime} \mathrm{E}$ & 330 & Goč & $43^{\circ} 33^{\prime} \mathrm{N}$ & $20^{\circ} 51^{\prime} \mathrm{E}$ & 990 \\
\hline Kragujevac & $44^{\circ} 02^{\prime} \mathrm{N}$ & $20^{\circ} 56^{\prime} \mathrm{E}$ & 190 & Vitkovac & $43^{\circ} 47^{\prime} \mathrm{N}$ & $20^{\circ} 48^{\prime} \mathrm{E}$ & 215 \\
\hline Gornja Dobrinja & $43^{\circ} 58^{\prime} \mathrm{N}$ & $20^{\circ} 05^{\prime} \mathrm{E}$ & 530 & Loboder & $43^{\circ} 44^{\prime} \mathrm{N}$ & $20^{\circ} 57^{\prime} \mathrm{E}$ & 500 \\
\hline Gornja Gorevnica & $43^{\circ} 58^{\prime} \mathrm{N}$ & $20^{\circ} 18^{\prime} \mathrm{E}$ & 340 & Vrnjačka Banja & $43^{\circ} 37^{\prime} \mathrm{N}$ & $20^{\circ} 54^{\prime} \mathrm{E}$ & 235 \\
\hline Gornja Trepča & $43^{\circ} 57^{\prime} \mathrm{N}$ & $20^{\circ} 29^{\prime} \mathrm{E}$ & 400 & Brezovica & $43^{\circ} 34^{\prime} \mathrm{N}$ & $20^{\circ} 59^{\prime} \mathrm{E}$ & 300 \\
\hline Vučkovica & $43^{\circ} 57^{\prime} \mathrm{N}$ & $20^{\circ} 48^{\prime} \mathrm{E}$ & 335 & & & & \\
\hline
\end{tabular}

coordinates of 53 rain gauges with their altitudes are also presented in Table 1. For our analysis, we use the daily-accumulated precipitation. We select samples from 27 convective precipitation events over a 15 -year period (1981-1995) in the treated area of approximately $6870 \mathrm{~km}^{2}$. The analysis performed is based on the following criteria: the convective precipitation has an intensity in excess of $2.5 \mathrm{~mm} \mathrm{~h}^{-1}$ and a duration of less than $2 \mathrm{~h}$, which only contributes to the daily accumulated precipitation. The event is observed by at least half of the rain gauge stations in the study area. The observations were performed after each convection event. The mean convective precipitation per event at rain gauges is presented in Table 2. The rain gauge networks have Hellmann rain gauges. The observations were performed after each convection event. A few stations have pluviographs.

\section{Model description}

The cloud-resolving mesoscale model which simulates the convective storm is described in detail by Ćurić et al. (2003,
2008). It represents a detailed portrait of the storm dynamics with fully interactive hydrometeors. The model used numerically integrates the time-dependent, nonhydrostatic and fully compressible equations. The dependent variables of the model are the Cartesian wind components; the perturbation potential temperature and pressure; the turbulent kinetic energy; and the mixing ratios for water vapor, cloud water and ice, rain, snow and hail (graupel). The model uses a generalized terrain-following coordinate with equal spacing in $x$ and $y$ directions as well as in the vertical.

The model domain was $150 \mathrm{~km} \times 85 \mathrm{~km} \times 20 \mathrm{~km}$ with a $500 \mathrm{~m}$ grid spacing in the horizontal direction. A constant vertical grid spacing of $200 \mathrm{~m}$ is used. The western boundary of the model area is displaced to the west with respect to that of the study area. The simulations were terminated at $t=120 \mathrm{~min}$. The wave radiating condition is applied to the lateral boundaries to minimize the reflection of waves that pass freely through the boundary. An upper boundary with a Rayleigh sponge layer is used, while the lower boundary is a free slip boundary.

The reference state is homogeneous in the horizontal direction with constant values of temperature, humidity, 
Table 2. Mean convective precipitation per event (in $\mathrm{mm}$ ) at raingauge stations.

\begin{tabular}{lclc}
\hline rain gauge stations & $\begin{array}{c}\text { Mean } \\
\text { convective } \\
\text { precipitation } \\
\text { per event } \\
(\mathrm{mm})\end{array}$ & rain gauge stations & $\begin{array}{c}\text { Mean } \\
\text { convective } \\
\text { recipitation } \\
\text { per event } \\
(\mathrm{mm})\end{array}$ \\
\hline Mionica & 24.2 & Gruža & 18.9 \\
Koštunići & 26.8 & Adžine Livade & 24.0 \\
Pranjani & 21.8 & Knić & 20.4 \\
Vukosavci & 25.8 & Ovčar Banja & 24.7 \\
Natalinci & 18.9 & Čačak & 21.2 \\
Rača & 17.3 & Požega & 23.9 \\
Ljig & 23.2 & Mojsinje & 21.2 \\
Štavice & 26.6 & Zakuta & 20.8 \\
Donja Šatornja & 21.5 & Bumbarevo Brdo & 18.7 \\
Breždje & 30.7 & Godačica & 21.9 \\
Donje Jarušice & 20.4 & Arilje & 25.5 \\
Rudnik & 25.0 & Guča & 23.9 \\
Stragari & 20.6 & Kaona-Dragačevska & 30.5 \\
Ćumić & 21.9 & Vrdila & 20.9 \\
Badnjevac & 17.0 & Kraljevo & 23.6 \\
Gornji Banjani & 28.0 & Vrba & 21.6 \\
Gornje Crnuće & 21.7 & Bjeluša & 30.2 \\
Pranjani & 21.8 & Katići & 30.1 \\
Divčibare & 31.8 & Ivanjica & 27.6 \\
Gornji Milanovac & 21.9 & Osonica & 30.3 \\
Topola & 18.2 & Kamenica & 23.0 \\
Bare & 19.4 & Goč & 29.4 \\
Kragujevac & 18.6 & Vitkovac & 19.4 \\
Gornja Dobrinja & 25.4 & Loboder & 23.1 \\
Gornja Gorevnica & 21.8 & Vrnjačka Banja & 23.4 \\
Gornja Trepča & 20.0 & Brezovica & 21.4 \\
Vučkovica & 19.0 & & \\
\hline & & & \\
\hline
\end{tabular}

pressure, wind velocity and wind direction. Convection was initiated by using an ellipsoidal warm cap with a $10 \mathrm{~km}$ horizontal axis and a $1.5 \mathrm{~km}$ vertical axis centered at the ground. The temperature perturbation used is $3 \mathrm{~K}$.

The convective storms were simulated with a model that critically depends on the model initial conditions. Initial conditions are usually given with a single sounding data. This approach has many disadvantages because the used vertical profiles are often totally unrepresentative in the boundary layer by the time convection begins. Quantitative estimates of the accumulated convective precipitation are therefore limited. For this reason, we have modified the temperature and wind profiles in the boundary layer by using the method explained by Ćurić and Janc (2011a). In our calculations the modified Belgrade midday routine soundings were used.

For the purpose of this study, single-moment bulk microphysics parameterization scheme is used as in other sensitivity studies of the similar type (Van den Heever and Cotton, 2004; Cohen and McCaul, 2006). The model microphysics represents cloud water, rain and three classes of ice (cloud ice, snow and hail). The microphysical equations and parameterizations are based on Ćurić and Janc (2011a). The shapes of all hydrometeors were assumed to be spherical, except for snow, which is in a hexagonal form with a maximum diameter (Lin et al., 1983). Hail and snow are each represented by an exponential size spectrum. Cloud ice spectrum is assumed to be monodispersed.

The advantage of the Khrgian-Mazin size distribution of cloud drops for prediction of the accumulated convective precipitation is demonstrated with Ćurić and Janc (2011a). For this reason, it is used in our simulations. The KhrgianMazin size distribution describes both the cloud droplet and raindrop spectra that are split by a diameter of $100 \mu \mathrm{m}$ (also called the unified Khrgian-Mazin size distribution). The unified Khrgian-Mazin size distribution may be written (Prupacher and Klett, 1997; Ćurić et al., 1998) as follows:

$N(D)=\frac{A D^{2}}{4} \exp \left(-\frac{B D}{2}\right)$

where

$A=1.452 \frac{\rho Q}{\rho_{\mathrm{W}} R_{M}^{6}} ; \quad B=\frac{3}{R_{M}}$.

In the above expression, $Q$ is the total liquid water mixing ratio; $R_{M}$ is the drop radius, which is used as a parameter and takes arbitrary values; $\rho_{\mathrm{W}}$ is the liquid water density; $\rho$ is the cloud air density; and $D$ is the drop diameter. In our model scheme we assumed that $R_{M}=50 \mu \mathrm{m}$ in agreement with the results of Ćurić and Janc (2011a).

\section{Comparison with observations}

The objective of this section is to describe the general characteristics of convective precipitation that produce flash floods in the study area and to determine whether the model version used reproduce successfully the observed areal accumulated convective precipitation values (hereafter called AACP) for selected events over a 15 -year period.

Hereafter we consider the convective precipitation from the individual convective storms occurring at a scale that is too small to be resolved by conventional observations. Besides data from the rain gauge network (Fig. 1), the available data from the operational "Hail Suppression Project" (Radinović, 1989) were also used in our analysis. This project uses rockets to inject seeding agent particles into hail clouds. Rockets are fired from a very dense network of launching sites (mean distance between sites is $5 \mathrm{~km}$ ). Voluntary observers report the days when convective precipitation from Cumulonimbus $(\mathrm{Cb})$ clouds occurred at their launching sites. The first radar echo of each analyzed convective storm was observed by $\mathrm{S}$ band radar located near Užice (west from area in Fig. 1). Unfortunately, only hail cells were monitored by radar according to the methodology of hail suppression. The convective storms whose observed duration time was less than $2 \mathrm{~h}$ are treated. Hereafter, we analyzed 


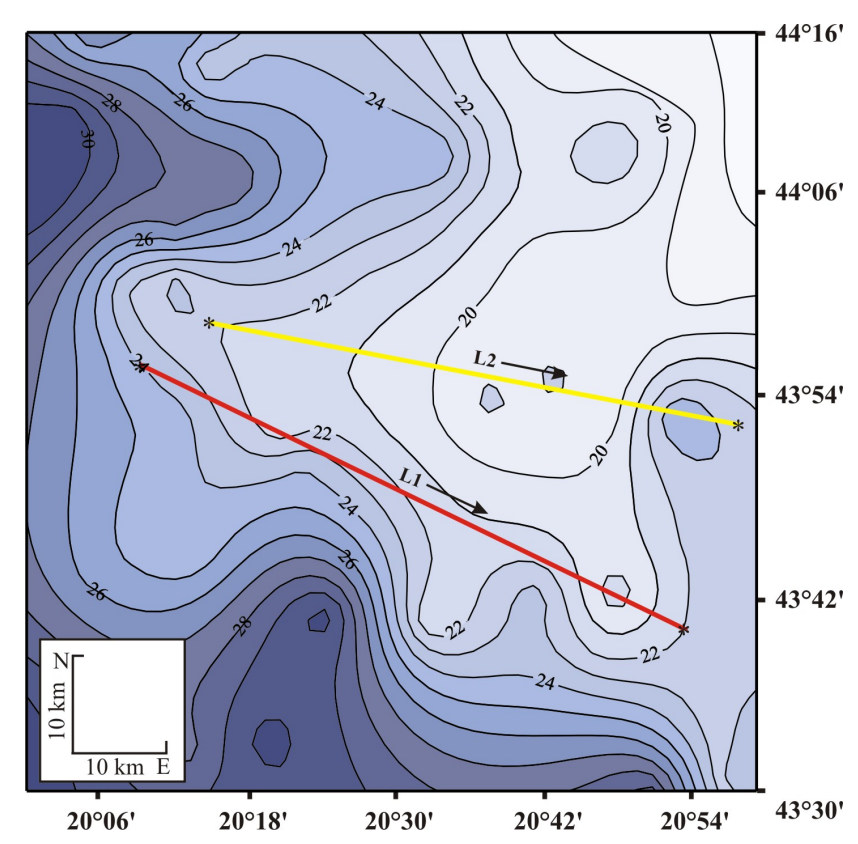

Fig. 2. Spatial distribution of the mean convective precipitation (in $\mathrm{mm})$ at the surface for the study area in Fig. 1. Precipitation is represented by isohyets with an icrement of $1 \mathrm{~mm}$. The L1 and L2 represent the most frequent tracks of the splitted storms from the NW direction.

the total convective precipitation. The selected convective storms were all initiated within the model domain in agreement with observations. The position of a warm bubble for each convective event is determined by the first radar echo. After initialization the convective storms pass through the growth phase without significant precipitation. Our focus is given to the convective precipitation from the split storms whose tracks are always in the study area (Fig. 2). The model used simulates the complete storm life cycle, but we compare the model and observed convective precipitation in the study area, which are mainly influenced by splitting. In comparisons we have made an effort to reproduce observed convective storms in real time.

The storm splitting cases are frequent over the treated study area (23 cases from 27 in total). The total accumulated precipitation production is highly dependent on the storm's propagation speed (Gilmore et al., 2004b). The AACP values are greater for the split storm cases than for the others. The spatial pattern of the split storm cases has a V-shape form (Ćurić and Janc, 2011a). This is due to the cloud splitting of the cyclonic (to the right) and anticyclonic (to the left) storms. For the non-split cases, the AACP field is in the form of a large continuous area.

Figure 2 demonstrates the spatial pattern of the mean convective precipitation in the study area. Two L1 and L2 directions are especially analysed because they are coincided with the tracks of right- and left-moving storms, respectively. As noted, the L1 direction (coincide roughly with the West

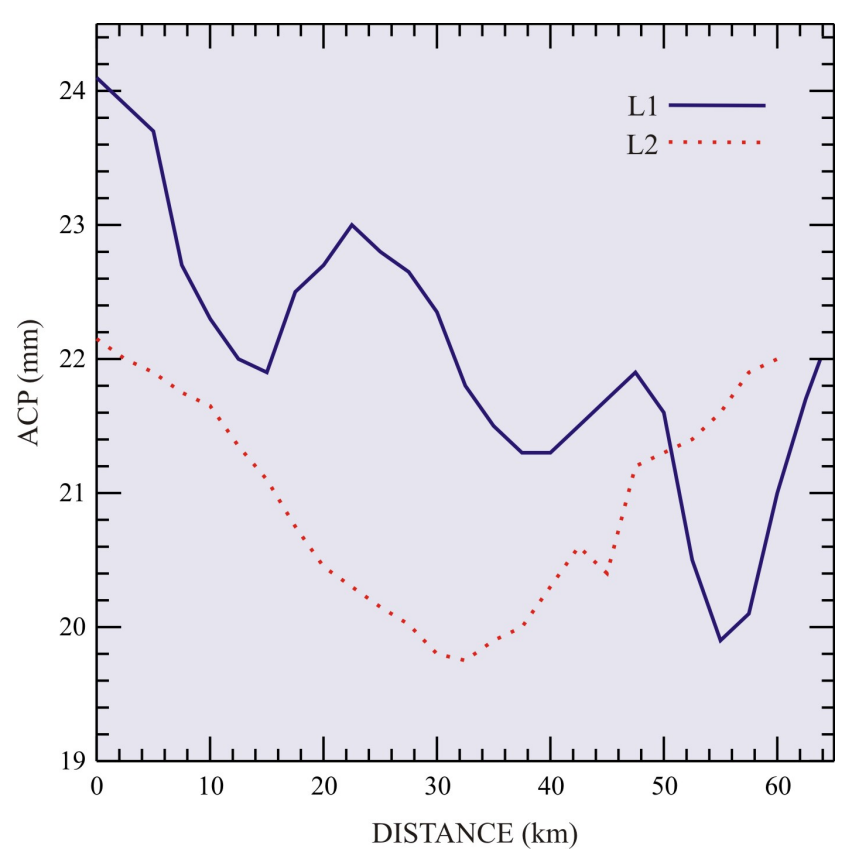

Fig. 3. Mean convective precipitation (ACP, in $\mathrm{mm}$ ) along the $\mathrm{L} 1$ and L2 tracks.

Morava river valley axes) is characterized by the alternate change of maxima and minima of the convective precipitation with the prevailing decrease trend from the northwest to the southeast as is shown in Fig. 3. This in agreement with the periodic precipitation characteristics of the right-moving cyclonic storm affected with the frequent front-side cell regeneration in presence of the valley (Ćurić, 1982; Ćurić et al., 2003). The L 2 track (north of the L1 one) is characterized by the non-periodic behavior of the convective precipitation with only one local minimum. It follows the left-moving anticyclonic storm which is generally unfavored within the existing environmental condition. This substantial different precipitation pattern may also be atributed to the less frequent front-cell regeneration outside the valley (Ćurić et al., 2003).

The reconstruction of AACP fields based on the punctual information is obtained by using data from the rain gauge networks and the launching sites. Isohyets are drawn by using the kriging as well as data about precipitation occurrence from the launching sites. Such a method is limited by the uncertain determination of the area that is encircled by an isohyet due to the spot-like rain gauge networks and the lack of the precipitation amounts from the launching sites. The first radar echo of convective storms is observed after 10:00 LT (local time).

We now analyze the AACP value for each convective precipitation event. Simultaneously, the model simulations are performed with the actual modified soundings. We then compare the sample of model AACP values with the observed values for the treated study area by using a statistical 


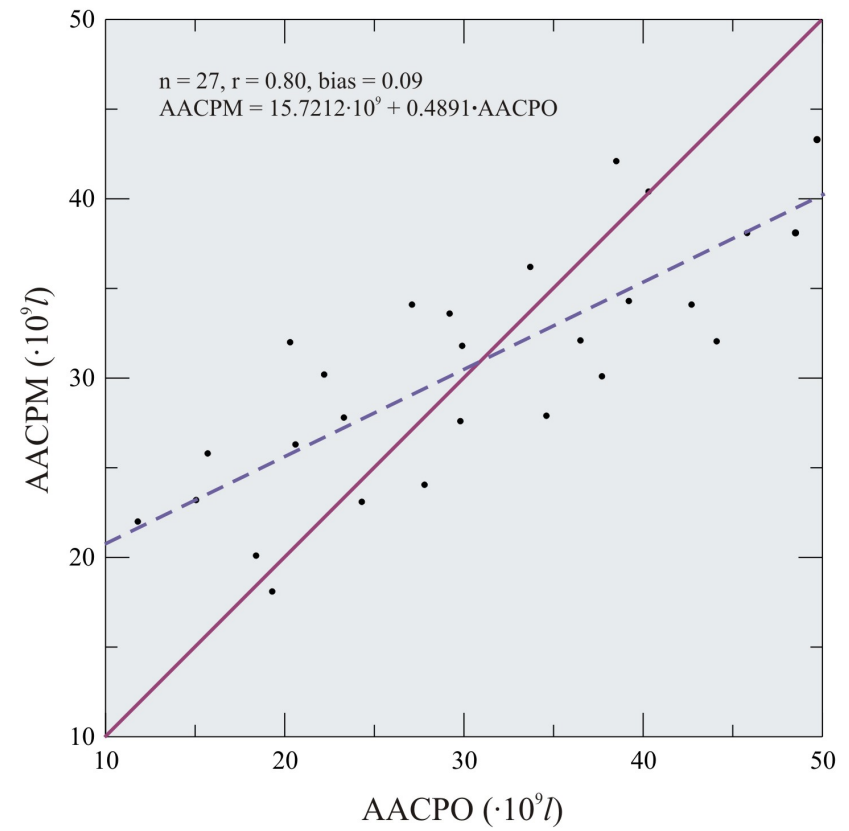

Fig. 4. Scatter diagram of model areal accumulated convective precipitation (AACPM) values $\left(10^{9} \ell\right)$ vs. their observed counterparts (AACPO) for the treated study area. The solid line is the 1:1 correspondence between model and observed values. The linear regression is presented with the dash line and the equation at upper part of the figure. Sample size $(n)$, correlation coefficient $(r)$ and bias are also shown.

analysis. Figure 4 represents the scatter diagram with the AACP model values versus their observed counterparts for the study area. The regression line (dash line) is also presented. The correlation coefficient between the observations and the model values is $r=0.80$, while the bias is +0.09 .

The cumulative relative frequency diagram (Fig. 5) shows the capabilities of our model to match the observed values of the AACP. It is evident that the model overestimates the observed values which are greater than $26 \times 10^{9} \ell$. This is in agreement with the nature of the Khrgian-Mazin size distribution that generates large amounts of smaller and mediumrange raindrops (Ćurić and Janc, 2011a). The general sample statistics for the observed and model AACP are presented in Table 3.

However, the good correlation between model and observed AACP datasets do not give us the information on how the model is able to simulate reliable spatial distribution of the accumulated convective precipitation. We selected two sites near the L1 track (Ovčar Banja and Kraljevo) and one site near the L2 track (Bumbarevo Brdo) - see Fig. 1. Figure 6 represents the scatter diagrams with the accumulated convective precipitation simulated by the model (ACPM) versus their observed counterparts for these rain gauge stations. As noted, the best linear correlation is found for Bumbarevo Brdo $(r=0.74)$. The correlation coefficients are lower than for the AACP values. Quantitative estimates
Table 3. General sample statistics for areal accumulated convective precipitation at the surface $(>5 \mathrm{~mm})$ expressed in $10^{9} \ell$ after $t=120 \mathrm{~min}$ for the observed (AACPO) and model values (AACPM).

\begin{tabular}{lll}
\hline $\begin{array}{l}\text { Sample } \\
\text { characteristics }\end{array}$ & $\begin{array}{l}\text { AACPO } \\
\left(\times 10^{9} \ell\right)\end{array}$ & $\begin{array}{l}\text { AACPM } \\
\left(\times 10^{9} \ell\right)\end{array}$ \\
\hline Sample size & 27 & 27 \\
Mean & 30.59 & 30.68 \\
Geometric mean & 28.58 & 29.97 \\
Median & 29.8 & 31.8 \\
Variance & 118.18 & 44.17 \\
Std. dev. & 10.87 & 6.64 \\
Minimum & 11.8 & 18.1 \\
Maximum & 49.7 & 43.3 \\
Range & 37.9 & 25.2 \\
Lower quartile & 21.4 & 26.0 \\
Upper quartile & 38.8 & 34.2 \\
Quartile range & 17.4 & 8.2 \\
Skewness & 0.09 & 0.04 \\
Kurtosis & -1.06 & -0.60 \\
\hline
\end{tabular}

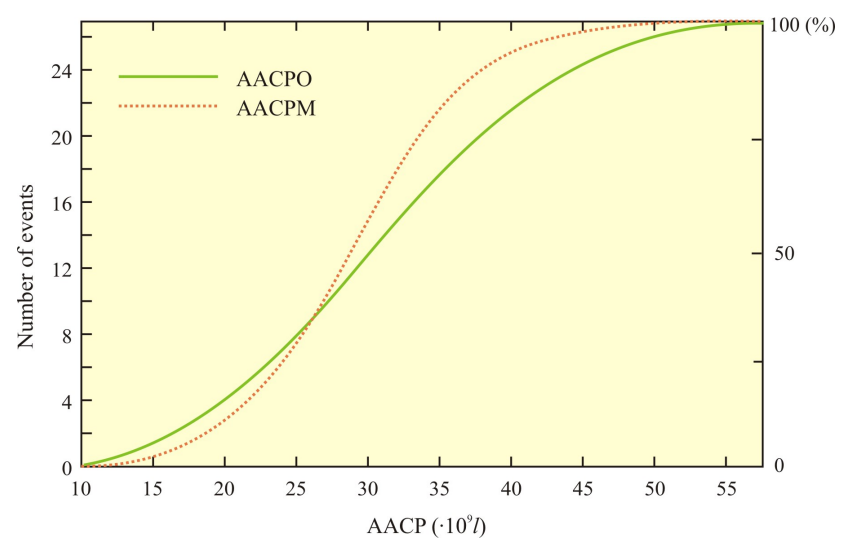

Fig. 5. Diagram of relative cumulative frequency (\%) for data shown in Fig. 4.

of the accumulated convective precipitation at the point are limited by deficiencies in the microphysical scheme and by limitations in the cloud-resolving model to simulate precisely the small-scale convective processes that are highly variable in space and time. The given results show the model capability to simulate the reliable spatial distribution of convective precipitation. Other general model limitations are: punctual information derived from the rain gauge data; a rainstorm initialization time and space is not fully coherent with the corresponding modified sounding; different propagation speeds of model and observed cloud; bulk microphysics scheme used etc. However, the cloud-resolving model with the carefully adjusted microphysical parameters within the bulk microphysical scheme may become a powerful tool for prediction 

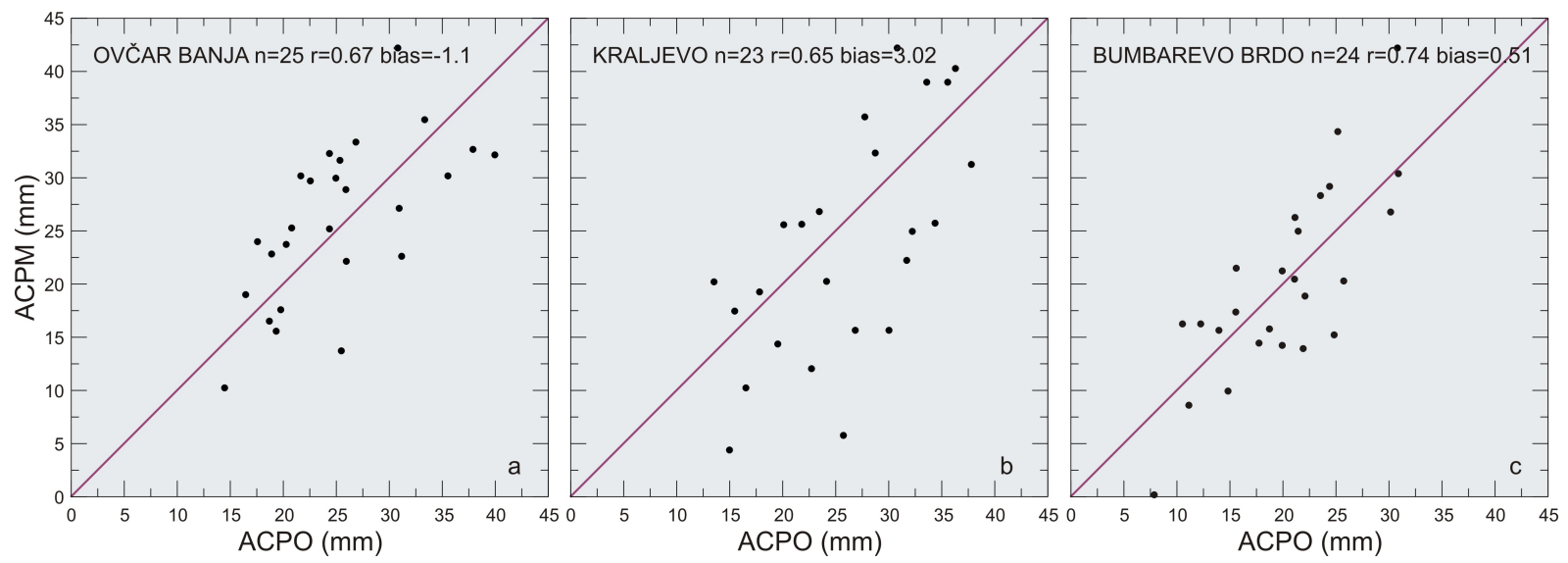

Fig. 6. Scatter diagrams of model accumulated convective precipitation, ACPM (mm), vs their observed counterparts, ACPO (mm), for rain gauge stations (a) Ovčar Banja, (b) Kraljevo and (c) Bumbarevo Brdo.

of the AACP values in the complex terrain case, where radar data are not available (or strongly limited in the case of a storm splitting). In the scope of this discussion this is important to emphasize that the better agreement between model and observed precipitation characteristics is found in flat land area (Ćurić and Janc, 2011a). This is due entirely to significant uncertainty of the quantitative precipitation estimates in complex terrain, low density of the rain gauge network as well as the model reference state which is not fully consistent with real case, especially in complex terrain. A correct simulation of the convective precipitation in time and space would contribute to improvements in hydrological analysis and predictions. In addition, the model has the capability to predict convective precipitation in the areas where neither radar data nor rain gauge data are available.

\section{Conclusions}

This study compares the areal accumulated convective precipitation from observations and its model values during a 15-year period in the study area with more frequent splitting cases. The main objective of this research is to demonstrate the capability of the cloud-resolving mesoscale model to match the observed Areal Accumulated Convective Precipitation (AACPO) values. We compared the observed dataset of 27 areal accumulated convective precipitation events to the model counterparts of the same precipitation events for study area by using a statistical analysis. The model microphysical scheme employed the unified Khrgian-Mazin gamma size distribution with a cloud drop radius of $50 \mu \mathrm{m}$.

The most striking conclusion from the present study is that the model and observed AACP values are well correlated (correlation coefficient of 0.80 ). This result demonstrates the capability of the model to reproduce successfully the accumulated convective precipitation affected by splitting process in a complex terrain. The complex spatial precipitation pattern is influenced with the type and distribution of the cells from which right- and left-moving storms are built. The cumulative relative frequency diagram is also presented to show how the model data match the observed counterparts. As noted, the model AACP values are somewhat overestimated over $26 \times 10^{9} \ell$. This may be attributed to the characteristics of the Khrgian-Mazin size distribution that generates a significantly higher concentration of small and medium-size raindrops. An additional analysis of the accumulated convective precipitation at the selected rain gauge stations shows that the model is able to simulate the reliable spatial distributions of the accumulated precipitation.

The results of this study suggest that the cloud-resolving mesoscale model is a valuable tool with which we can examine the convective precipitation, both in reproducing existing observed values and in making predictions. We must emphasize that the disagreement between the observed and the model convective precipitation characteristics should not be always attributed to the uncertainty in the model microphysics. The input data from a single sounding are often unrepresentative, especially in areas far away from the sounding site. On the other hand, the radar data are often unavailable or they are worse estimation of the convective precipitation intensity, while the rain gauge networks may be coarse or totally absent. In light of these unfavorable occasions, the model can give reasonable estimation of AACP. Thanks to the rapid development of computational resources, the use of the cloud-resolving mesoscale models for operational purposes will soon be possible. In such a way, these models may become major contributors to improvements in hydrological analysis and predictions.

Acknowledgements. This research was supported by the Ministry of Science of Serbia. We gratefully acknowledge Mr. Dragomir Bulatović for technical preparation of the figures. 
Edited by: M. Werner

\section{References}

Adlerman, E. J., Droegemeier, K. K., and Davies-Jones, R.: A numerical simulation of cyclonic mesocyclogenesis, J. Atmos. Sci., 56, 2045-2069, 1999.

Amengual, A., Romero, R., Gomez, M., Martin, A., and Alonso, S.: A hydrometeorological modeling study of a flash-flood event over Catalonia, Spain, J. Hydrometeorol., 8, 282-303, 2007.

Barnolas, M., Rigo, T., and Llasat, M. C.: Characteristics of 2-D convective structures in Catalonia (NE Spain): an analysis using radar data and GIS, Hydrol. Earth Syst. Sci., 14, 129-139, doi:10.5194/hess-14-129-2010, 2010.

Bongioannini Cerlini, P., Emanuel, K. A., and Todini, E.: Orographic effects on convective precipitation and space-time rainfall variability: preliminary results, Hydrol. Earth Syst. Sci., 9, 285-299, doi:10.5194/hess-9-285-2005, 2005.

Chumchean, S., Seed, A., and Sharma, A.: Correcting of radar mean field bias using Kalman filtering approach, J. Hydrol., 317, 123-137, 2006.

Cohen, C. and McCaul Jr., E. W.: The sensitivity of simulated convective storms to variations in prescribed single-moment mycrophysics parameters that describe particle distributions, sizes, and numbers, Mon. Weather Rev., 134, 2547-2565, 2006.

Ćurić, M.: The development of the cumulonimbus clouds which moves along a valley, in: Cloud Dynamics, edited by: Agee, E. M. and Asai, T., D. Reidel, Dordrecht, 259-272, 1982.

Ćurić, M. and Janc, D.: Mountain influence on the areal characteristics of types of convective precipitation, Theor. Appl. Climatol., 45, 71-76, 1992.

Ćurić, M. and Janc, D.: Comparison of modeled and observed accumulated convective precipitation in mountainous and flat land areas, J. Hydrometeorol., 12, 245-261, 2011 a.

Ćurić, M. and Janc, D.: Differential heating influence on hailstorm vortex pair evolution, Q. J. Roy. Meteorol. Soc., doi:10.1002/qj918, in press, 2011 b.

Ćurić, M., Janc, D., and Vučković, V.: On the sensitivity of cloud microphysics under influence of cloud drop size distribution, Atmos. Res., 47-48, 1-14, 1998.

Ćurić, M., Janc, D., Vujović, D., and Vučković, V.: The effects of a river valley on an isolated cumulonimbus cloud development, Atmos. Res., 66, 123-139, 2003.

Ćurić, M., Janc, D., and Vučković, V.: Precipitation change from a Cumulonimbus cloud downwind of a seeded target area, J. Geophys. Res., 113, D11215, doi:10.1029/2007JD009483, 2008.

Ćurić, M., Janc, D., Vučković, V.: The influence of merging and individual storm splitting on mesoscale convective system formation, Atmos. Res., 93, 21-29, 2009.

Droegemeier, K. K., Smith, J. D., Businger, S., Doswell III, C., Doyle, J., Duffy, C., Foufoula-Georgiou, E., Graziano, T., James, L. D., Krajewski, V., LeMone, M., Lettenmaier, D., Mass, C., Pielke Sr., P., Ray, P., Rutledge, S., Schaake, J., and Zipser, E.: Hydrological Aspects of Weather Prediction and Flood Warnings: Report of the Ninth Prospectus Development Team of the U.S. Weather Research Program, B. Am. Meteorol. Soc., 75, 2665-2680, 2000.

Gilmore, M. S., Straka, J. M., and Rasmussen, E. N.: Precipitation uncertainty due to variations in precipitation particle parameters within a simple microphysics scheme, Mon. Weather Rev., 132, 2610-2627, 2004a.

Gilmore, M. S., Straka, J. M., and Rasmussen, E. N.: Precipitation and evolution sensitivity in simulated deep convective storms: Comparisons between liquid-only and simple ice and liquid phase microphysics, Mon. Weather Rev., 132, 1897-1916, $2004 b$.

Grasso, L. D. and Hilgendorf, E. R.: Observations of a severe left moving thunderstorm, Weather Forecast., 16, 500-511, 2001.

Hunter, S.M.: WSR-88D radar rainfall estimation: capabilities, limitations and potential improvements, Natl. Wea. Dig., 20, 26-38, 1996.

Lin, Y. L., Farley, R. D., and Orville, H. D.: Bulk parameterization of the snow field in a cloud model, J. Clim. Appl. Meteorol., 22, 1065-1092, 1983.

Lovejoy, S. and Schertzer, D.: Multifractals, cloud radiances and rain, J. Hydrol., 322, 59-88, 2006.

Niyogy, D., Pyle, P., Lei, M., Arya, S. P., Kishtawal, C. M., Shepherd, M., Chen, F., and Wolfe, B.: Urban modification of thunderstorms - An observational storm climatology and model case study for the Indianopolis Urban Region. J. Appl. Meteorol. Clim., doi:10.1175/2010JAMC1836.1, 50, 1129-1144, 2011.

Pruppacher, H. R. and Klett, J.D.: Microphysics of clouds and precipitation, 2nd Edn., Kluwer Academic Publishers, 954 pp. 1997.

Radinović, D.: Effectiveness of hail control in Serbia, J. Wea. Mod., 21, 75-84, 1989.

Richard, E., Cosma, S., Benoit, R., Binder, P., Buzzi, A., and Kaufmann, P.: Intercomparison of mesoscale meteorological models for precipitation forecasting, Hydrol. Earth Syst. Sci., 7, 799811, doi:10.5194/hess-7-799-2003, 2003.

Sayed, K. H., Goodrich, D. C., Myers, D. E., and Soroshian, S.: Spatial characteristics of thunderstorm rainfall fields and their relation to runoff, J. Hydrol., 271, 1-21, 2003.

Sempere Torres, D. S., Porra, J. M., and Creutin, J. D.: A general formulation for raindrop size distribution, J. Appl. Meteorol., 33, 1494-1502, 1994.

Spiridonov, V. and Ćurić, M.: The relative importance of scavenging, oxidation, and ice-phase processes in the production and wet deposition of sulfate, J. Atmos. Sci., 62, 2118-2135, 2005.

Tao, W. K., Simpson, J., and McCumber, M.: An ice-water saturation adjustment, Mon. Weather Rev., 117, 231-235, 1989.

Uijlenhoet, R. and Pomeroy, J. H.: Raindrop size distributions and radar reflectivityrain rate relationships for radar hydrology, Hydrol. Earth Syst. Sci., 5, 615-628, doi:10.5194/hess-5-615-2001, 2001.

Van den Heever, S. C. and Cotton, W. R.: The impact of hail size on simulated supercell storms, J. Atmos. Sci., 61, 1596-1609, 2004.

Willems, P.: A spatial rainfall generator for small spatial scales, J. Hydrol., 252, 126-144, 2001.

Xue, M., Droegemeier, K. K., Wong, W., Shapiro, A., Brewster, K., Carr, F., Weber, D., Liu, Y., and Wang, D.: The Advanced Regional Prediction System (ARPS)-a multi-scale nonhydrostatic atmospheric simulation and prediction model: Part II. Model physics and applications, Meteorol. Atmos. Phys., 76, 143-165, 2001.

Young, C. B., Nelson, B. R., Bradley, A. A., Smith, J. A., PetersLilard, C. D., Kruger, A., and Baeck, M. L.: An evaluation of NEXRAD precipitation estimates in complex terrain, J. Geophy. Res., 104, 19691-19703, 1999. 